\title{
ABATEMENT OF PARTICULATE MATTER EMISSION FROM EXPERIMENTAL BROILER HOUSINGS USING AN OPTIMIZED OIL SPRAYING METHOD
}

\author{
A. Winkel, M. Cambra-López, P. W. G. Groot Koerkamp， N. W. M. Ogink, A. J. A. Aarnink
}

\begin{abstract}
In this follow-up study, we investigated effects of two rapeseed oil application rates ( 8 or $16 \mathrm{~mL} \mathrm{~m}^{-2} d^{-1}$ ) in combination with two spraying frequencies (daily or every other day) in four oil treatments: $8 \mathrm{~mL} \mathrm{~m} \mathrm{~m}^{-2}(24 \mathrm{~h})^{-1}, 16 \mathrm{~mL} \mathrm{~m}$ $(48 \mathrm{~h})^{-1}, 16 \mathrm{~mL} \mathrm{~m}^{-2}(24 \mathrm{~h})^{-1}$, and $32 \mathrm{~mL} \mathrm{~m}^{-2}(48 \mathrm{~h})^{-1}$ during two growth cycles of broilers. Oil treatments were randomly assigned to four rooms, whereas two rooms served as control $\left(0 \mathrm{~mL} \mathrm{~m} \mathrm{~m}^{-2}\right)$. Oil spraying started on day 21. Prior to the second growth cycle, the spraying system was optimized to improve the distribution of oil and reduce the generation of small oil particles. We measured ventilation rate and concentrations of $P M_{10}, P M_{2.5}$, ammonia, and odor. Furthermore, we recorded bird performance and birds' exterior quality. $P M_{10}$ emission was significantly reduced by $59 \%$ at $8 \mathrm{~mL} \mathrm{~m}^{-2} d^{-1}$ and by $64 \%$ at $16 \mathrm{~mL} \mathrm{~m}^{-2} d^{-1}$. For $P M_{2.5}$, these values were $81 \%$ and $74 \%$, respectively. In the two every other day treatments, $P M_{10}$ emission was $44 \%$ higher on days after spraying than on spraying days. No significant effect of oil spraying was found on ammonia emission, odor emission, bird performance, and birds' exterior quality. The latter finding confirms that the incidence of foot-pad lesions is not increased at an application rate of $16 \mathrm{~mL} \mathrm{~m}^{-2} d^{-1}$. It is recommended to validate the

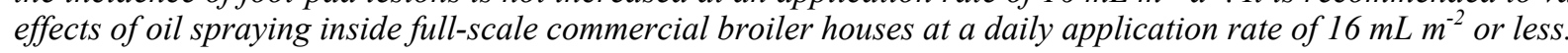

Keywords. Broiler house, Foot-pad lesions, Odor, Oil spraying, Particulate matter.

$\mathrm{I}$ n many parts of the world, broiler chickens are reared inside mechanically ventilated buildings that house up to tens of thousands of birds on litter floors. The presence of litter (i.e., manure and bedding material), together with the feathers of the broilers, gives rise to high concentrations of airborne particulate matter (PM) (Cambra-López et al., 2011; Winkel et al., 2014). The abundance of PM in the air of poultry houses is associated with an increased risk of respiratory diseases in poultry farmers (Omland, 2002; Radon et al., 2001). In broilers, exposure to airborne PM may devitalize the respiratory mucosa; damage bronchi, lungs, and air sacs; facilitate the invasion of micro-organisms; and affect body weight gain and mortality (Al Homidan et al., 2003; Madelin and Wathes, 1989). By their exhaust emissions, broiler houses may raise PM concentration in the ambient environment and thereby adversely affect respiratory and cardiovascular health of the

Submitted for review in July 2014 as manuscript number SE 10870; approved for publication by the Structures \& Environment Division of ASABE in October 2014.

The authors are Albert Winkel, Researcher, Wageningen UR Livestock Research, Wageningen, The Netherlands; María CambraLópez, Researcher, Institute of Animal Science and Technology, Universidad Polytéchnica de Valencia, Valencia, Spain; Peter Groot Koerkamp, Professor, Farm Technology Group, Wageningen University, and Senior Researcher, Wageningen UR Livestock Research, Wageningen, The Netherlands; Nico Ogink, Senior Researcher, Wageningen UR Livestock Research, Wageningen, The Netherlands; André Aarnink, ASABE Member, Senior Researcher, Wageningen UR Livestock Research, Wageningen, The Netherlands. Corresponding author: Albert Winkel, Wageningen UR Livestock Research, P.O. Box 338, 6700 AH Wageningen, The Netherlands; phone: +31-317-480491; email: albert.winkel@wur.nl. general population (Brunekreef and Holgate, 2002). In The Netherlands, intensive livestock farming has been identified as the third largest source of particles with aerodynamic diameters smaller than $10 \mu \mathrm{m}\left(\mathrm{PM}_{10}\right)$, responsible for approximately $17 \%$ of the primary $\mathrm{PM}_{10}$ emitted nationally (RIVM, 2014). Limit concentrations for the ambient environment have been laid down by the European Union in EU directive 2008/50/EC (EU, 2008) for $\mathrm{PM}_{10}$ and for particles with aerodynamic diameters smaller than $2.5 \mu \mathrm{m}\left(\mathrm{PM}_{2.5}\right)$. Mitigation options for the most relevant PM sources are urgently needed to be able to comply with these limits and protect the population. Therefore, a research program was initiated with the aim of developing PM mitigation options for the poultry industry, which were selected based on their efficacy and economic feasibility (Ogink and Aarnink, 2011).

One of these options is spraying vegetable oil to prevent particles on surfaces (e.g., litter floors) from becoming airborne. The effects of spraying oil, or oil-water mixtures, have been studied in pig houses (Takai, 2007), but only a few studies have been carried out in broiler houses (Drost et al., 1999; Griffin and Vardaman, 1970; McGovern et al., 1999, 2000). The latter studies investigated oil spraying from the perspective of improving indoor air quality and the performance and health of the broilers. None of these studies focused on the abatement of PM emissions to the ambient environment.

In a previous study (Aarnink et al., 2011), we used an oil spraying system installed inside four rooms of an experimental broiler house to investigate the dose-response effects of spraying rapeseed oil $\left(6\right.$ to $24 \mathrm{~mL} \mathrm{~m}^{-2} \mathrm{~d}^{-1}$ daily 
spraying) on the reduction of PM and ammonia emissions, on workers' exposure to PM, and on the performance and exterior quality of the broilers. That study showed that $\mathrm{PM}_{10}$ concentration and emission decreased with increasing oil application rate, but no effect was found on ammonia emission and bird performance. However, the system produced small oil particles ( $<10 \mu \mathrm{m}$ aerodynamic diameter) during spraying, and the application of $24 \mathrm{~mL} \mathrm{~m}^{-2} \mathrm{~d}^{-1}$ significantly increased the incidence and severity of foot-pad lesions as compared to the control treatment $\left(0 \mathrm{~mL} \mathrm{~m}^{-2}\right)$. Based on that study, it was advised not to exceed a maximum application rate of $16 \mathrm{~mL} \mathrm{~m}^{-2} \mathrm{~d}^{-1}$.

In this article, we report a follow-up study to Aarnink et al. (2011) that was carried out in the same broiler house. The objective of this follow-up study was to further increase our understanding of the effects of oil application rate and application frequency on particulate and gaseous emissions, bird performance, and birds' exterior quality. More explicitly, the main research questions within this study were:

- What is the effect of spraying oil daily versus a double dose every other day?

- What is the effect of oil spraying on odor emission?

- What is the effect of system optimizations on the generation of small oil particles?

- What is the effect of application rates of $16 \mathrm{~mL} \mathrm{~m}^{-2} \mathrm{~d}^{-1}$ or less on the exterior quality of the broilers?

\section{MATERIAL AND METHODS EXPERIMENTAL DESIGN}

We investigated the effect of two oil application rates (8 or $16 \mathrm{~mL} \mathrm{~m}^{-2} \mathrm{~d}^{-1}$ ) in combination with two spraying frequencies (daily or every other day), resulting in four oil treatments: $8 \mathrm{~mL} \mathrm{~m}^{-2}(24 \mathrm{~h})^{-1}, 16 \mathrm{~mL} \mathrm{~m}^{-2}(48 \mathrm{~h})^{-1}, 16 \mathrm{~mL} \mathrm{~m}^{-2}$ $\left(24 \mathrm{~h}^{-1}\right.$, and $32 \mathrm{~mL} \mathrm{~m}^{-2}(48 \mathrm{~h})^{-1}$. Oil treatments were randomly assigned to four broiler rooms, and two rooms served as control $\left(0 \mathrm{~mL} \mathrm{~m}^{-2}\right)$. The experiment lasted for two consecutive growth cycles. In both cycles, oil spraying started on day 21.

\section{Housing AND ANIMALS}

The study was conducted inside the broiler house at Het Spelderholt experimental station in Lelystad, The Netherlands. Each room measured $8.32 \times 16.06 \mathrm{~m}\left(133.6 \mathrm{~m}^{2}\right)$ and contained four feeding lines with seven feeders and eight drinking lines with 180 drinking nipples in total. The rooms were heated by a central heating system with radiators on the side walls underneath the air inlets. In each room 2,675 one-day-old Ross 308 broilers (Probroed en Sloot, Groenlo, The Netherlands) were placed. The broilers were delivered at 35 days of age, at approximately 2.0 to $2.1 \mathrm{~kg}$ live weight. Broilers had ad libitum access to feed and drinking water. They were vaccinated against infectious bronchitis, Gumboro, and Newcastle disease. The broilers received a pre-starter diet (crumb feed) during the first ten days, followed by a starter diet (granules and 15\% wheat) on days 11 to 28, and a finisher diet (granules and 30\% wheat) on days 29 to 35 (Superreeks diet, ForFarmers, Lochem, The
Netherlands). During the first two days, the rooms were continuously lit. During the rest of the growth cycle an intermittent light scheme was used of $8 \mathrm{~h}$ light and $4 \mathrm{~h}$ dark (07:45 to $15: 45$ light, $15: 45$ to $19: 45$ dark, $19: 45$ to $03: 45$ light, and 03:45 to 07:45 dark). Light intensity was the same for all rooms (20 lux).

Between growth cycles, litter was removed, and feeders and drinking lines were pretreated with a cleaning agent (Pro-Rein, CID Lines, Ieper, Belgium; 26 kg in 400 L water). After $30 \mathrm{~min}$ of soaking time, the rooms were cleaned with a high-pressure cleaner using tap water. One day before the broilers were introduced, $1 \mathrm{~kg} \mathrm{~m}^{-2}$ of fresh wood shavings was spread in the rooms as bedding material. All rooms were heated to $33^{\circ} \mathrm{C}$ three days before the broilers were placed in the rooms. The target temperatures at the different ages were $33^{\circ} \mathrm{C}$ at day $1,28^{\circ} \mathrm{C}$ at day $7,25^{\circ} \mathrm{C}$ at day $14,22^{\circ} \mathrm{C}$ at day 21 , and $20^{\circ} \mathrm{C}$ at day 35 (the temperatures between these days were linearly interpolated). Each room had 12 air inlets in the side walls and three variablespeed exhaust fans in the roof $\left(0.6 \mathrm{~m}\right.$ diameter, $7000 \mathrm{~m}^{3} \mathrm{~h}^{-1}$ capacity per fan, Fancom B.V., Panningen, The Netherlands). One fan operated continuously, and the other two operated when needed. Minimum ventilation was controlled at $1 \mathrm{~m}^{3} \mathrm{~h}^{-1}$ per $\mathrm{kg}$ live weight. Based on the inside temperature, the ventilation rate was increased automatically by the climate computer (type FSU.4, Fancom B.V., Panningen, The Netherlands). The maximum ventilation rate in the room was $21,000 \mathrm{~m}^{3} \mathrm{~h}^{-1}$, or $7.9 \mathrm{~m}^{3} \mathrm{~h}^{-1}$ bird $^{-1}$.

\section{OIL SPRAYING SYSTEM}

During the first growth cycle, the same oil spraying system as in Aarnink et al. (2011) was used. This system consisted of full-cone nozzles (type SU26B-SSBR, Spraying Systems, Ridderkerk, The Netherlands) installed on oil tubes (fig. 1). Two oil tubes (PVC Kiwa tube, $32 \mathrm{~mm}$ dia.) were suspended across the center of the room in parallel at a height of approximately $2.5 \mathrm{~m}$. Four nozzles were placed on each tube, pointing in opposite directions. Each tube with nozzles had to cover half the area of the room $(8 \times 8 \mathrm{~m})$. Oil was sprayed by injecting oil and air into the nozzles at the same time, both at a pressure of 3.5 bar. Compressed air was delivered through tubes underneath the oil tubes (PVC Kiwa tube, $32 \mathrm{~mm}$ dia.). Air and oil pressure was provided by a compressor (type CV 40, $3.0 \mathrm{~kW}, 400 \mathrm{VAC}, 50 \mathrm{~Hz}$ ) with an air dryer (model DE 101, $230 \mathrm{VAC}, 0.36 \mathrm{~kW}$, max. 16 bar, min. $5^{\circ} \mathrm{C}$, $\max .43^{\circ} \mathrm{C}$; Airpress, Euro series, V.R.B. Friesland B.V., Leeuwarden, The Netherlands). Oil and air delivery to the nozzles was controlled by valves (BE 024AS, $24 \mathrm{VAC}$, $50 \mathrm{~Hz}, 10 \mathrm{~W}$; Danfoss, Hasselager, Denmark). The valves were opened for a certain time depending on how much oil needed to be sprayed in the room. The spraying was automatically controlled by a control unit (Moeller Easy 821DC-TC, F-Central software, Fancom, Panningen, The Netherlands). The oil was delivered from a high-pressure tank (24 L, model N24, Mondeo, Montecchio Maggiore, Italy). Pure, cold-pressed, and refined rapeseed oil (0.91 $\mathrm{g} \mathrm{mL}^{-1}$ density) was used. This oil was suitable for use as a biofuel for vehicles.

To achieve a more uniform distribution of oil over the litter floor, the oil spraying system was expanded prior to 


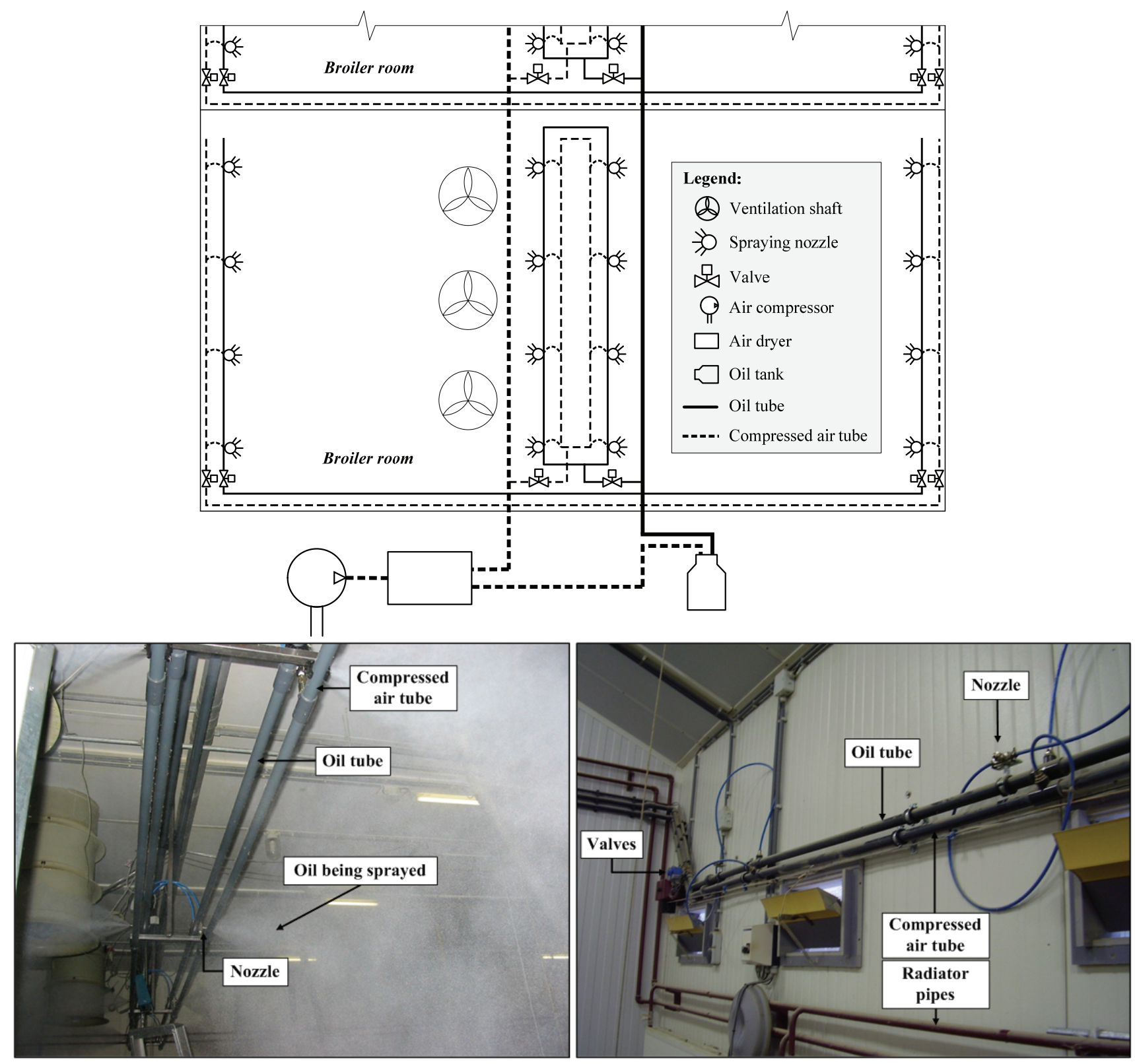

Figure 1. Schematic plan view (top) and photographs of the oil spraying system during spraying (bottom left) and the extra side wall nozzles spraying toward the center of the room (bottom right).

the second growth cycle, with two additional oil tubes per room mounted on the side walls (fig. 1). Both additional oil tubes contained four nozzles, thereby increasing the number of nozzles per room from eight to sixteen, and decreasing the floor area per tube from half of the room to a quarter of the room. The side wall nozzles sprayed toward the center of the room. To minimize the formation of small oil particles, the oil pressure and air pressure were decreased in the second growth cycle from 3.5 to 3.0 bar. At these configurations, the volume median diameter of the oil particles was increased from 44 to $49 \mu \mathrm{m}$, respectively (Aarnink and Van Hattum, 2009).

\section{Treatments}

The oil spraying treatments were $8 \mathrm{~mL} \mathrm{~m}^{-2}(24 \mathrm{~h})^{-1}$, $16 \mathrm{~mL} \mathrm{~m}^{-2}\left(48 \mathrm{~h}^{-1}, 16 \mathrm{~mL} \mathrm{~m}^{-2}\left(24 \mathrm{~h}^{-1}\right.\right.$, and $32 \mathrm{~mL} \mathrm{~m}^{-2}$
$(48 \mathrm{~h})^{-1}$. The relationship between spraying time and the amount of oil applied found by Aarnink et al. (2011) $\left(0.4 \mathrm{~mL} \mathrm{~m}^{-2} \mathrm{~s}^{-1}\right)$ was used to determine spraying duration. Spraying times in the first growth cycle were $20 \mathrm{~s}$ for application of $8 \mathrm{~mL} \mathrm{~m}^{-2}, 40 \mathrm{~s}$ for application of $16 \mathrm{~mL} \mathrm{~m}^{-2}$, and $80 \mathrm{~s}$ for application of $32 \mathrm{~mL} \mathrm{~m}^{-2}$. In the second growth cycle, these spraying times were halved because twice as many nozzles were used. No clear change in oil application rate was found due to the reduction of oil and air pressure from 3.5 to 3.0 bar. Previous work showed that PM concentrations and emissions strongly increased only after two to three weeks (Aarnink et al., 2011). Therefore, we started the oil spraying at day 21 of the growth cycle. On oil spraying days, oil was sprayed once, normally at 8:00. On the second day of each $24 \mathrm{~h}$ PM sampling period, oil was sprayed at 14:00 to protect the PM sampling equipment, which sampled from noon to noon. 


\section{MEASUREMENTS} ble 1 .

An overview of the measured variables is given in ta-

\section{Particulate Matter Concentration}

Measurements of $\mathrm{PM}_{10}$ and $\mathrm{PM}_{2.5}$ concentrations were done on four days spread over the growth cycle: on day 16 , when oil spraying had not yet started, and during the oil spraying phase on days 23, 30, and 33 in both growth cycles. Duplicate PM samplers for sampling exhaust air were placed in each room near the shaft of the ventilator that was continuously running, $0.5 \mathrm{~m}$ horizontally from the edge of the exhaust opening and $0.1 \mathrm{~m}$ vertically below the exhaust opening. In the incoming air, single samples of $\mathrm{PM}_{10}$ and $\mathrm{PM}_{2.5}$ were taken just outside the animal house. Sampling times were from noon to noon $(24 \mathrm{~h})$. These measurements were carried out to determine concentrations and emissions of PM.

$\mathrm{PM}_{10}$ and $\mathrm{PM}_{2.5}$ concentrations were determined by gravimetric filtration using sampling pumps (Tecora, model Charlie HV, Ravebo B.V., Brielle, The Netherlands) and cyclone samplers (model URG-2000-30ENB for $\mathrm{PM}_{10}$ and URG-2000-30EG for $\mathrm{PM}_{2.5}$, URG Corp., Chapel Hill, N.C.) at a sample flow rate of $16.7 \mathrm{~L} \mathrm{~min}^{-1}$. Inside the cyclones, the aimed particle size was collected on a glass fiber filter (type GF-3, $47 \mathrm{~mm}$ dia., Macherey-Nagel, Düren, Germany). Unloaded and loaded filters were weighed with a precise balance (AT261 DeltaRange, Mettler, Greifensee, Switzerland; $10 \mu \mathrm{g}$ resolution) under standard conditions of $20^{\circ} \mathrm{C} \pm 1{ }^{\circ} \mathrm{C}$ and $50 \% \pm 5 \%$ relative humidity (CEN, 1998 , 2005). After $48 \mathrm{~h}$ of stabilization, the filters were weighed four times over two consecutive days. The average value was recorded as the filter weight. The PM mass concentration was calculated by dividing the mass of collected PM by the volume of air drawn through the filter. $\mathrm{PM}_{10}$ concentrations were calibrated to the reference impaction sampler described in EN 12341 (CEN, 1998) using the equations reported by Zhao et al. (2009): $y=1.09 x$ when $x \leq 223 \mu \mathrm{g}$ $\mathrm{m}^{-3}$ and $y=0.83 x+57.5$ when $x>223 \mu \mathrm{g} \mathrm{m}^{-3}$, where $x$ is the concentration measured with the cyclone sampler, and $y$ is the calibrated concentration.

To assess the generation of small oil particles of the adapted oil spraying system during the second growth cycle, $\mathrm{PM}_{10}$ and $\mathrm{PM}_{2.5}$ concentrations were additionally measured during the time around oil spraying on days 25 and 31. On these days, PM was sampled during $2 \mathrm{~h}$ (from 15 min before until 105 min after oil spraying) following the same procedures as described above.

\section{Personal PM ${ }_{10}$ Sampling}

The exposure of stock handlers to PM was determined on days 25,32 , and 33 in the first growth cycle and on days 25 and 32 in the second growth cycle using a lightscattering device (DustTrak aerosol monitor, model 8520, TSI, Inc., Shoreview, Minn.). The DustTrak was attached to the stock handler's lapel, at a height of approximately $1.5 \mathrm{~m}$, with the sampling inlet facing upward. Stock handlers wore respiratory masks to prevent directly breathing into the inlet. On a measuring day, the stock handler simulated daily animal care routine activities following a standard procedure for $7 \mathrm{~min}$ per room. Concentrations of $\mathrm{PM}_{10}$ $\left(\mathrm{mg} \mathrm{m}^{-3}\right)$ close to the nose and mouth were measured each second and logged as 1 min means in the memory of the device.

\section{Ammonia Concentration}

Ammonia concentrations were measured semicontinuously by continuously sampling air from each room and by sequentially measuring concentrations in each room for 5 min with a NOx monitor (model ML8840, Monitor Labs, Englewood, Colo.). Aerial ammonia was first converted to $\mathrm{NO}$ at $775^{\circ} \mathrm{C}$ by separate converters for each room. Exhaust air was sampled inside the shaft of the ventilator that was continuously running. The monitor was calibrated weekly with a gas of $40 \mathrm{ppm} \mathrm{NO}$ in nitrogen $\left(\mathrm{N}_{2}\right)$, and the flow rate was checked. For each 5 min sampling

Table 1. Summary of measured variables.

\begin{tabular}{|c|c|c|c|c|c|}
\hline Variable & $\begin{array}{c}\text { Measurement } \\
\text { Method or Instrument }\end{array}$ & Unit & $\begin{array}{l}\text { Sampling } \\
\text { Duration }\end{array}$ & $\begin{array}{c}\text { Time } \\
\text { Resolution }\end{array}$ & $\begin{array}{c}\text { Frequency } \\
\text { (days in growth cycle) }\end{array}$ \\
\hline \multicolumn{6}{|l|}{ Particulate matter concentration } \\
\hline $\mathrm{PM}_{10}$ and $\mathrm{PM}_{2.5}$ & Cyclone sampler & $\mathrm{mg} \mathrm{m}^{-3}$ & $24 \mathrm{~h}$ & $24 \mathrm{~h}$ & $16,23,30$, and 33 \\
\hline $\mathrm{PM}_{10}$ and $\mathrm{PM}_{2.5}$ during oil spraying & Cyclone sampler & $\mathrm{mg} \mathrm{m}^{-3}$ & $2 \mathrm{~h}$ & $2 \mathrm{~h}$ & 25 and 31 (2nd cycle) \\
\hline Personal $\mathrm{PM}_{10}$ exposure & DustTrak aerosol monitor & $\mathrm{mg} \mathrm{m}^{-3}$ & $7 \mathrm{~min}$ & $1 \mathrm{~min}$ & $\begin{array}{c}25,32 \text {, and } 33 \text { ( } 1 \text { st cycle); } \\
25 \text { and } 32 \text { (2nd cycle) }\end{array}$ \\
\hline Ammonia concentration & $\mathrm{NH}_{3}$ converter, $\mathrm{NO}_{\mathrm{x}}$ monitor & $\mathrm{mg} \mathrm{m}^{-3}$ & Continuous & - & - \\
\hline Odor concentration & Dynamic olfactometry & $\mathrm{OU}_{\mathrm{E}} \mathrm{m}^{-3}$ & $2 \mathrm{~h}$ & $2 \mathrm{~h}$ & 24 and 31 \\
\hline Ventilation rate & Ventilation shaft anemometers & $\mathrm{m}^{-3} \mathrm{~h}^{-1}$ & Continuous & $1 \mathrm{~h}$ & - \\
\hline \multicolumn{6}{|l|}{ Environmental conditions } \\
\hline Air temperature & Temperature sensor & ${ }^{\circ} \mathrm{C}$ & Continuous & $1 \mathrm{~h}$ & - \\
\hline Relative humidity & Relative humidity sensor & $\%$ & Continuous & $1 \mathrm{~h}$ & - \\
\hline \multicolumn{6}{|l|}{ Animal parameters } \\
\hline Body weight & Weighing & $\mathrm{g}$ & - & - & $0,21,34$, and 35 \\
\hline Feed consumption & Feed weighing system & $\mathrm{kg} \mathrm{d}^{-1}$ room $^{-1}$ & - & - & 21 and 35 \\
\hline Water consumption & Water meter & $\mathrm{Ld} \mathrm{d}^{-1}$ room $^{-1}$ & Continuous & 1 day & Daily \\
\hline Mortality & Visual inspection, counting & $\%$ & Continuous & 1 day & Daily \\
\hline Foot-pad lesions & Visual observation, scoring & Score & - & - & 33 \\
\hline Exterior quality & Visual observation, scoring & Score & - & - & 33 \\
\hline Rapeseed oil use & Weighing & $\mathrm{kg} \mathrm{d}^{-1}$ room $^{-1}$ & Continuous & 1 day & Daily \\
\hline \multicolumn{6}{|l|}{ Litter characteristics } \\
\hline Dry matter content & Oven-drying, weighing & $\%$ & - & - & 14,28 , and 35 \\
\hline Manure cake formation & Visual observation & $\%$ of litter area & - & - & 14,28 , and 35 \\
\hline Room cleaning time & Visual observation & $\min$ & - & - & 36 \\
\hline
\end{tabular}


period per room, only the data from the last minute were used, and hourly mean ammonia concentrations were stored in a data logger.

\section{Odor Concentration}

Odor concentrations were measured on days 24 and 31 in both growth cycles. On these days, air samples were taken from 10:00 to 12:00 in each room using the lung principle (vessels with $40 \mathrm{~L}$ Nalophan air sampling bags connected to electrical pumps; model 607CD32, Thomas Industries, Inc., Wabasha, Minn.; $0.5 \mathrm{~L} \mathrm{~min}^{-1}$ critical capillary). The pump removed air from the vessel, which caused the sampling bag to be filled with air taken from the room. The air samples were transported and stored according to EN 13725 (CEN, 2003), and odor concentrations (in European odor units, $\mathrm{OU}_{\mathrm{E}}$ ) were determined by olfactometry within $30 \mathrm{~h}$ after sampling.

\section{Ventilation Rate, Temperature, and Humidity}

The ventilation rate in all three ventilation shafts was measured with calibrated anemometers (ATM.56, Fancom, Panningen, The Netherlands) of the same diameter as the ventilation shafts. Hourly means were stored in a data logger. Temperature and relative humidity $(\mathrm{RH})$ outside and inside each room, near the ventilation shaft, were continuously measured with combined temperature/humidity sensors (HygroClip, Rotronic AG, Bassersdorf, Switzerland). The accuracy of these sensors was $\pm 1.0^{\circ} \mathrm{C}$ and $\pm 2 \% \mathrm{RH}$. Hourly means were stored in a data logger.

\section{Animal Parameters}

All broilers were weighed on arrival at the broiler house (day 0) and before transport to the processing plant (day $35)$ by group weighing of birds in transportation crates. Furthermore, a sample of 100 broilers per room (50 males, 50 females) was weighed on day 21 (just before oil spraying started) and day 34. The amount of feed delivered to each room was recorded daily by the automatic feed weighing unit of the house, and the amount of water was recorded by separate water meters. Mortality numbers were recorded daily per room. Foot-pad lesions and bird exterior quality were scored in samples of 100 broilers per room (50 males, 50 females) on day 33 of both growth cycles. Foot-pad lesions were scored according to the protocol described by Berg (1998). Within this protocol, the foot-pads of the broilers are scored in three classes: class $0=$ lesions absent or minor, class $1=$ medium lesions, and class $2=$ severe lesions. The final foot-pad score is calculated as follows: $100 \times[$ (number of birds in class $0 \times 0)+$ (number of birds in class $1 \times 0.5)+($ number of birds in class $2 \times 2)$ ] / total number of birds scored. Bird exterior quality was scored on breast dirtiness, breast irritations, scabby hips (thigh scratches), and hock burns in four classes (none, mild, medium, or severe), as described by Van Harn (2009).

\section{Oil Spraying}

The amount of oil sprayed was measured daily by weighing the oil storage tank before and after spraying on a platform weighing unit (type FB 64EDE571205413, maximum capacity $64 \mathrm{~kg}, 0.4 \times 0.3 \mathrm{~m}$ platform, Sartorius, Nieuwegein, The Netherlands). The time needed to clean the rooms was recorded at the end of both growth cycles.

\section{Litter Characteristics}

On days 14, 28, and 35 of the growth cycle, litter samples were taken at six spots in each room (approx. $0.5 \mathrm{~kg}$ per room). The dry matter content of these samples was determined by weighing before and after oven-drying for $24 \mathrm{~h}$ at $105^{\circ} \mathrm{C}$. On the same days, the percentage of the litter floor being either friable or covered with solid manure cake was scored by visual observation.

\section{DATA Preparation ANd ANALYSIS \\ Calculation of Emission Rates}

Emission rates of PM and ammonia were calculated using equation 1 :

$$
\text { Emission }=\left(C_{\text {exhaust }}-C_{\text {inlet }}\right) \times Q
$$

where

Emission $=$ emission rate $\left(\mathrm{mg} \mathrm{h}^{-1}\right.$ for $\mathrm{PM}_{10}, \mathrm{PM}_{2.5}$, and ammonia; $\mathrm{OU}_{\mathrm{E}} \mathrm{s}^{-1}$ for odor)

$C_{\text {exhaust }}=$ exhaust air concentration $\left(\mathrm{mg} \mathrm{m}^{-3}\right.$ for $\mathrm{PM}_{10}$, $\mathrm{PM}_{2.5}$, and ammonia; $\mathrm{OU}_{\mathrm{E}}$ for odor)

$C_{\text {inlet }}=$ inlet air concentration $\left(\mathrm{mg} \mathrm{m}^{-3}\right.$ for $\mathrm{PM}_{10}, \mathrm{PM}_{2.5}$, and ammonia; $\mathrm{OU}_{\mathrm{E}}$ for odor)

$Q=$ ventilation rate $\left(\mathrm{m}^{3} \mathrm{~h}^{-1}\right.$ for $\mathrm{PM}_{10}, \mathrm{PM}_{2.5}$, and ammonia; $\mathrm{m}^{3} \mathrm{~s}^{-1}$ for odor).

\section{Estimation of Airborne $\mathrm{PM}_{10}$ or PM $\mathrm{PM}_{2.5}$ Oil Particles}

Based on the $\mathrm{PM}_{10}$ and $\mathrm{PM}_{2.5}$ concentration measurements during the time around oil spraying on days 25 and 31 in the second growth cycle, the proportion of oil applied measured as airborne particles in the $\mathrm{PM}_{10}$ and $\mathrm{PM}_{2.5}$ fraction was estimated using equation 2 :

$$
P M_{\text {oil }}=\frac{\left[E_{k}-\left(1-\eta_{k}\right) \times E_{\text {control }}\right] \times T \times \frac{1}{\rho}}{A} \times 100
$$

where

$P M_{\text {oil }}=$ proportion of oil applied measured as airborne $\mathrm{PM}_{10}$ or $\mathrm{PM}_{2.5}$ oil particles (\%)

$E_{k}=$ emission of $\mathrm{PM}_{10}$ or $\mathrm{PM}_{2.5}$ in treatment $k$ during oil spraying $\left(\mathrm{g} \mathrm{h}^{-1}\right)$

$\eta_{k}=$ relative reduction of $\mathrm{PM}_{10}$ or $\mathrm{PM}_{2.5}$ in treatment $k$ ( 0 to 1 , based on the PM measurements outside spraying times)

$E_{\text {control }}=$ emission of $\mathrm{PM}_{10}$ or $\mathrm{PM}_{2.5}$ of control rooms during oil spraying $\left(\mathrm{g} \mathrm{h}^{-1}\right)$

$T=$ sampling duration around oil spraying (h)

$\rho=$ density of rapeseed oil $\left(0.91 \mathrm{~g} \mathrm{~mL}^{-1}\right)$

$A=$ application of oil $\left(1069 \mathrm{~mL}^{\text {room }}{ }^{-1}\right.$ at $8 \mathrm{~mL} \mathrm{~m}^{-2}$ $2138 \mathrm{~mL} \mathrm{room}^{-1}$ at $16 \mathrm{~mL} \mathrm{~m}^{-2}$, and $4275 \mathrm{~mL} \mathrm{room}^{-1}$ at $32 \mathrm{~mL} \mathrm{~m}^{-2}$ ).

In equation 2, the emission of PM from oil spraying rooms during spraying $\left(E_{k}\right)$ is assumed to consist of oil particles and regular PM from litter and feathers. The amount of regular $\mathrm{PM}$ in $E_{k}$ is estimated by $\left(1-\eta_{k}\right) \times E_{\text {control }}$, whereas the amount of oil particles in $E_{k}$ is determined by subtracting the amount of regular PM from $E_{k}$. 
Table 2. Mean ventilation rate, indoor and outside temperature, and relative humidity in the different treatments and growth cycles.

\begin{tabular}{|c|c|c|c|c|c|c|c|}
\hline \multirow[b]{2}{*}{ Parameter } & \multirow[b]{2}{*}{$\begin{array}{c}\text { Growth } \\
\text { Cycle }\end{array}$} & \multirow[b]{2}{*}{ Outside } & \multirow{2}{*}{$\begin{array}{c}\text { Control } \\
\text { Rooms } \\
\left(0 \mathrm{~mL} \mathrm{~m}^{-2}\right)\end{array}$} & \multicolumn{2}{|c|}{$8 \mathrm{~mL} \mathrm{~m}^{-2} \mathrm{~d}^{-1}$} & \multicolumn{2}{|c|}{$16 \mathrm{~mL} \mathrm{~m}^{-2} \mathrm{~d}^{-1}$} \\
\hline & & & & $\begin{array}{c}8 \mathrm{~mL} \mathrm{~m}^{-2} \\
(24 \mathrm{~h})^{-1}\end{array}$ & $\begin{array}{c}16 \mathrm{~mL} \mathrm{~m}^{-2} \\
(48 \mathrm{~h})^{-1}\end{array}$ & $\begin{array}{c}16 \mathrm{~mL} \mathrm{~m}^{-2} \\
(24 \mathrm{~h})^{-1}\end{array}$ & $\begin{array}{c}32 \mathrm{~mL} \mathrm{~m}^{-2} \\
(48 \mathrm{~h})^{-1}\end{array}$ \\
\hline Ventilation rate & 1 & - & 1.88 & 2.02 & 1.93 & 1.94 & 1.92 \\
\hline$\left(\mathrm{m}^{3} \mathrm{~h}^{-1}\right.$ bird $\left.^{-1}\right)$ & 2 & - & 1.65 & 1.73 & 1.69 & 1.62 & 1.67 \\
\hline Temperature & 1 & 16.6 & 25.7 & 25.7 & 25.9 & 26.5 & 25.7 \\
\hline$\left({ }^{\circ} \mathrm{C}\right)$ & 2 & 16.1 & 25.2 & 24.9 & 25.1 & 25.2 & 25.0 \\
\hline Relative humidity & 1 & 75.6 & 59.4 & 59.4 & 57.7 & 58.4 & 59.3 \\
\hline$(\%)$ & 2 & 83.4 & 64.2 & 64.3 & 63.9 & 65.9 & 64.0 \\
\hline
\end{tabular}

\section{Statistical Analysis}

Reductions in emission rates of $\mathrm{PM}_{10}$ and $\mathrm{PM}_{2.5}$ relative to the mean of control rooms were estimated and tested for significance with a longitudinal regression model which recognizes that repeated measurements over time were done within rooms. The treatments were split up in the model into effects of oil application rate $\left(0,8\right.$, or $16 \mathrm{~mL} \mathrm{~m}^{-2}$ $\mathrm{d}^{-1}$ ) and effects of spraying frequency (daily or every other day). Interaction effects between oil application rate, spraying frequency, growth cycle, and day in the growth cycle were not statistically significant and were therefore omitted from the final model, which is described by equation 3 :

$$
\log \left(\underline{Y}_{i j k l m n}\right)=\alpha_{i}+\beta_{j}+a \cdot \gamma_{k}+\theta_{l}+\underline{\varepsilon}_{m}+\underline{\varepsilon}_{m n}+\underline{\varepsilon}_{i j k l m n}
$$

where

$\log \left(\underline{Y}_{i j k l m n}\right)=$ response variable, i.e., the natural logarithm of the $\mathrm{PM}_{10}$ or $\mathrm{PM}_{2.5}$ emission rate of oil application rate $i$ and spraying frequency $j$, on relative moment $k$ on day $l$ of growth cycle $m$ inside room $n$

$\alpha_{i}=$ effect of oil application rate $i\left(0,8\right.$, or $\left.16 \mathrm{~mL} \mathrm{~m}^{-2} \mathrm{~d}^{-1}\right)$

$\beta_{j}=$ effect of spraying frequency $j$ (daily or every other day)

$a=$ regression coefficient

$\gamma_{k}=$ moment of the measurement in relation to the last oil spraying $k$ (on the same day or on the day after)

$\theta_{l}=$ effect of day $l$ in the growth cycle $(23,30$, and 33$)$

$\underline{\varepsilon}_{m}=$ random growth cycle effect: $\underline{\varepsilon}_{m} \sim N\left(0, \sigma_{m}{ }^{2}\right)$

$\varepsilon_{m n}=$ random room effect within growth cycles: $\varepsilon_{m n} \sim$ $N\left(0, \sigma_{m n}{ }^{2}\right)$

$\underline{\varepsilon}_{i j k l m n}=$ random day effect correlated within rooms (autoregression), variance different between weeks: $\underline{\varepsilon}_{i j k l m n}$ $\sim N\left(0 ; \Sigma \tau_{j}, \phi_{l}^{t}\right)$.

The model described in equation 3 was also used to test significant differences between treatments and control for emission rates of ammonia and odor, with the only modification that treatments were not split into separate effects of oil application rate and spraying frequency. Bird performance data of days 0 to 21 (before oil spraying had started) and of days 0 to 35 were both analyzed by analysis of variance (ANOVA), with mean values per treatment and growth cycle as the experimental units, treatment as the explanatory factor, and growth cycle as block. Foot-pad lesions and exterior quality parameters were analyzed using the IR Class test because frequencies were not normally distributed over the categories. All analyses were done using the GenStat software (VSN, 2012), and probability values $<0.05$ were considered statistically significant.

\section{RESULTS}

\section{FunCtioning OF THE OIL SPRAYING System}

During this study, oil leakage from the nozzles was observed, and therefore we mounted a small bucket underneath each nozzle. Per eight nozzles, the system applied on average $0.38 \mathrm{~mL} \mathrm{~m}^{-2}$ per second of spraying time. In the second growth cycle, when the system had two additional oil tubes along the side walls of each room, we visually observed that oil was distributed more uniformly over the litter floor in comparison to the configuration in the first growth cycle.

\section{VENTILATION RATE, TEMPERATURE, AND HUMIDITY}

Mean ventilation rate, indoor and outside temperature, and relative humidity in the different treatments and growth cycles are given as descriptive statistic in table 2. Figure 2 shows the patterns of the ventilation rate per treatment and growth cycle. From the overlapping lines in this figure, it is
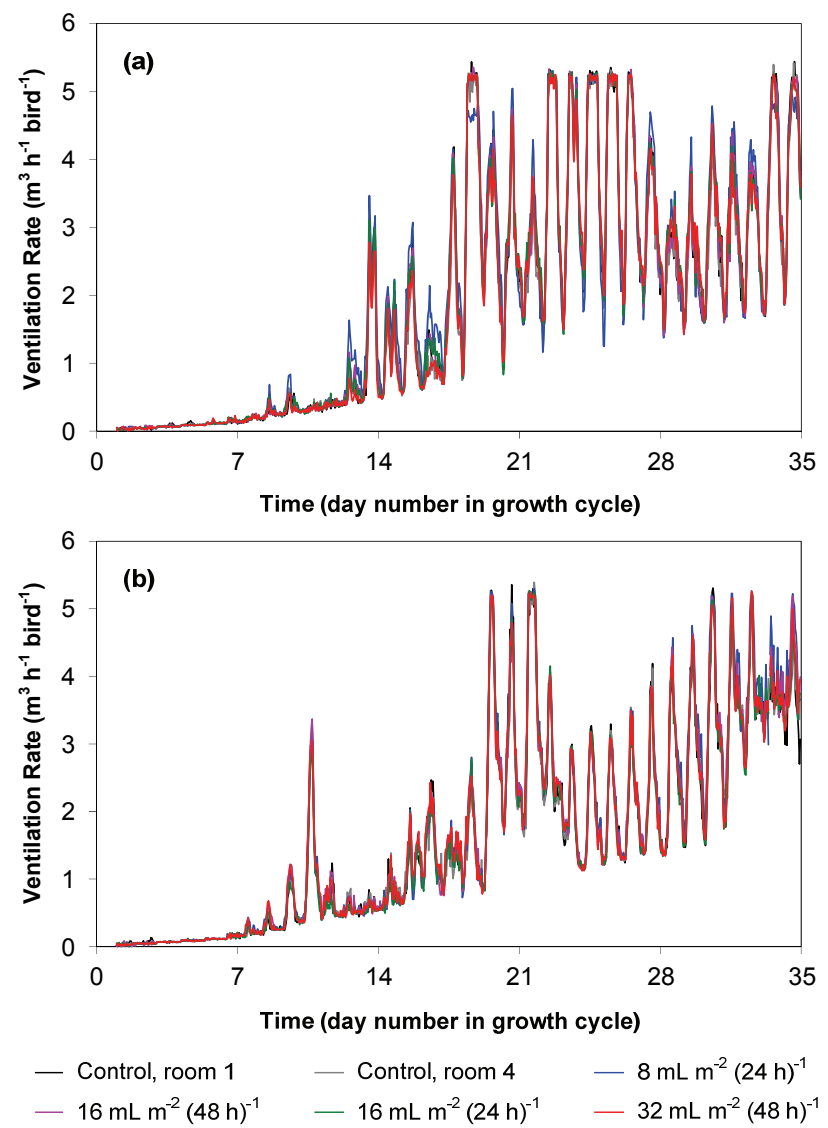

Figure 2. Ventilation rates during the (a) first and (b) second growth cycles. Note that the treatment lines mostly overlap. 
clear that the ventilation rates were very similar between rooms. Ventilation rates increased with the age of the broilers, and ventilation rate was higher during the day than at night after the second week, resulting in a spiked and gradually increasing pattern. The mean ventilation rate was $1.94 \mathrm{~m}^{3} \mathrm{~h}^{-1}$ bird $^{-1}$ in the first growth cycle and $1.67 \mathrm{~m}^{3} \mathrm{~h}^{-1}$ bird $^{-1}$ in the second growth cycle. Indoor temperature and relative humidity were similar between treatments (table 2).

\section{Particulate Matter Concentrations AND EMISSIONS}

Table 3 shows mean concentrations and emission rates of $\mathrm{PM}_{10}$ and $\mathrm{PM}_{2.5}$ per growth cycle and treatment. The mean (standard deviation, SD) concentrations at the air inlet were $0.023(0.015) \mathrm{mg} \mathrm{m}^{-3}$ for $\mathrm{PM}_{10}$ and $0.016(0.007)$ $\mathrm{mg} \mathrm{m}^{-3}$ for $\mathrm{PM}_{2.5}$. On day 16 of the growth cycle, when oil spraying had not yet started, the mean (SD) $\mathrm{PM}_{10}$ concentration was $0.739(0.215) \mathrm{mg} \mathrm{m}^{-3}$ in the control rooms and $0.751(0.150) \mathrm{mg} \mathrm{m}^{-3}$ in the oil treatment rooms, and the mean (SD) $\mathrm{PM}_{2.5}$ concentration was $0.050(0.037) \mathrm{mg} \mathrm{m}^{-3}$ in the control rooms and $0.053(0.049) \mathrm{mg} \mathrm{m}^{-3}$ in the oil treatment rooms.

With regard to oil application rate $\left(\alpha_{i}\right.$ in eq. $3 ; 0,8$, or $16 \mathrm{~mL} \mathrm{~m}^{-2} \mathrm{~d}^{-1}$ ), the statistical analysis showed that, relative to the control treatment, $\mathrm{PM}_{10}$ emission was significantly reduced by spraying oil at 8 or $16 \mathrm{~mL} \mathrm{~m}^{-2} \mathrm{~d}^{-1}(\mathrm{p}=0.006)$. The model-estimated reductions in $\mathrm{PM}_{10}$ emission were $59 \%$ for $8 \mathrm{~mL} \mathrm{~m}^{-2} \mathrm{~d}^{-1}$ and $64 \%$ for $16 \mathrm{~mL} \mathrm{~m}^{-2} \mathrm{~d}^{-1}$, but no significant difference was found between these two oil application rates. Relative to the control treatment, $\mathrm{PM}_{2.5}$ emission was significantly reduced by oil spraying at 8 or $16 \mathrm{~mL} \mathrm{~m}^{-2} \mathrm{~d}^{-1}(\mathrm{p}<0.001)$. The model-estimated reductions in $\mathrm{PM}_{2.5}$ emission were $81 \%$ for $8 \mathrm{~mL} \mathrm{~m}^{-2} \mathrm{~d}^{-1}$ and $74 \%$ for $16 \mathrm{~mL} \mathrm{~m}^{-2} \mathrm{~d}^{-1}$, but no significant difference was found between these two oil application rates.

With regard to spraying frequency $\left(\beta_{j}\right.$ in eq. 3 ; daily or every other day), the statistical analysis showed that neither the $\mathrm{PM}_{10}$ emission nor the $\mathrm{PM}_{2.5}$ emission differed significantly between the every other day treatment and the daily treatment.

With regard to the moment of the measurement in relation to the last oil spraying ( $a \cdot \gamma_{k}$ in eq. 3 ; on the same day or on the day after), the model-estimated $\mathrm{PM}_{10}$ emission on days after spraying was $44 \%$ higher than on spraying days, which was borderline significant $(\mathrm{p}=0.05)$. However, for $\mathrm{PM}_{2.5}$ emission, no significant difference was found between days after spraying and spraying days.

Figure 3 shows the measured concentrations of $\mathrm{PM}_{10}$
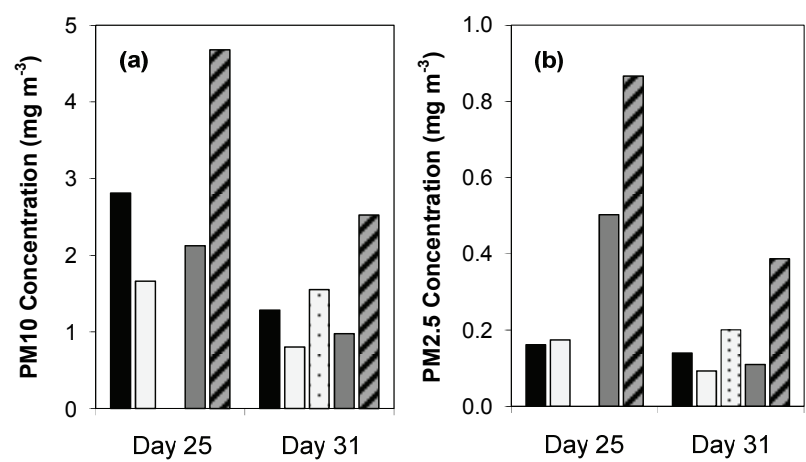

$$
\begin{aligned}
\text { Control }\left(0 \mathrm{~mL} \mathrm{~m}{ }^{-2}\right) & \square 8 \mathrm{~mL} \mathrm{~m}^{-2}(24 \mathrm{~h})^{-1} \\
\square 16 \mathrm{~mL} \mathrm{~m}^{-2}(24 \mathrm{~h})^{-1} & \square 32 \mathrm{~mL} \mathrm{~m}^{-2}(48 \mathrm{~h})^{-1}
\end{aligned}
$$

Figure 3. Concentrations of $\mathbf{P M}_{10}$ (a) and $\mathbf{P M}_{2.5}$ (b) around the time of oil spraying on day 25 (from 7:45 to 9:45) and day 31 (from 13:00 to 15:00) in the second growth cycle. Due to a technical problem, no values were obtained on day 25 in the $16 \mathrm{~mL} \mathrm{~m}^{-2}(48 \mathrm{~h})^{-1}$ room.

and $\mathrm{PM}_{2.5}$ during the time around oil spraying (days 25 and 31 in the second growth cycle). In comparison to the control treatment, $\mathrm{PM}_{10}$ and $\mathrm{PM}_{2.5}$ concentrations were elevated in the $32 \mathrm{~mL} \mathrm{~m}^{-2}(48 \mathrm{~h})^{-1}$ treatment on both measuring days by a mean factor of 1.8 for $\mathrm{PM}_{10}$ and 4.1 for $\mathrm{PM}_{2.5}$. For the three rooms where 8 or $16 \mathrm{~mL} \mathrm{~m}^{-2}$ was applied, concentrations were similar to the control treatment, except for one $\mathrm{PM}_{2.5}$ concentration value on day 25 in the $16 \mathrm{~mL}$ $\mathrm{m}^{-2}\left(24 \mathrm{~h}^{-1}\right.$ room. Based on equation 2, the mean (standard error of the mean, SEM) percentage of applied oil sampled as airborne oil particles was $1.84 \%(0.26 \%)$ for the $\mathrm{PM}_{10}$ fraction and $0.34 \%(0.02 \%)$ for the $\mathrm{PM}_{2.5}$ fraction.

The mean concentrations measured during personal $\mathrm{PM}_{10}$ sampling are presented in figure 4. From this figure, it is clear that, relative to the control treatment, $\mathrm{PM}_{10}$ exposure was lower in all oil spraying treatments. Two sets of data are shown in figure 4 . The left set of bars shows results from days when oil was sprayed in the daily treatments only. The right set of bars shows results from days when oil was sprayed in all (daily and every other day) treatments. In the left set of bars, exposure tends to be more reduced in the daily treatments where oil had been applied earlier that day. In the right set of bars, exposure tends to decrease with increasing oil application rate. The mean reduction in $\mathrm{PM}_{10}$ exposure was $60 \%$ for the $8 \mathrm{~mL} \mathrm{~m}^{-2}$ $(24 \mathrm{~h})^{-1}$ treatment, $61 \%$ for the $16 \mathrm{~mL} \mathrm{~m}^{-2}(48 \mathrm{~h})^{-1}$ treatment, $80 \%$ for the $16 \mathrm{~mL} \mathrm{~m}^{-2}(24 \mathrm{~h})^{-1}$ treatment, and $63 \%$ for the $32 \mathrm{~mL} \mathrm{~m}^{-2}(48 \mathrm{~h})^{-1}$ treatment.

Table 3. Descriptive statistics (number of data points, mean, and standard deviation in parentheses) of $\mathbf{P M} \mathbf{M}_{10}$ and $\mathbf{P M}_{2.5}$ concentrations and

\begin{tabular}{|c|c|c|c|c|c|c|c|}
\hline \multirow[b]{2}{*}{ Parameter } & \multirow[b]{2}{*}{$\begin{array}{c}\text { Growth } \\
\text { Cycle }\end{array}$} & \multirow[b]{2}{*}{$n$} & \multirow{2}{*}{$\begin{array}{c}\text { Control } \\
\text { Rooms } \\
\left(0 \mathrm{~mL} \mathrm{~m}^{-2}\right)\end{array}$} & \multicolumn{2}{|c|}{$8 \mathrm{~mL} \mathrm{~m}^{-2} \mathrm{~d}^{-1}$} & \multicolumn{2}{|c|}{$16 \mathrm{~mL} \mathrm{~m}^{-2} \mathrm{~d}^{-1}$} \\
\hline & & & & $\begin{array}{l}8 \mathrm{~mL} \mathrm{~m}^{-2} \\
(24 \mathrm{~h})^{-1}\end{array}$ & $\begin{array}{c}16 \mathrm{~mL} \mathrm{~m}^{-2} \\
(48 \mathrm{~h})^{-1}\end{array}$ & $\begin{array}{c}16 \mathrm{~mL} \mathrm{~m}^{-2} \\
(24 \mathrm{~h})^{-1}\end{array}$ & $\begin{array}{c}32 \mathrm{~mL} \mathrm{~m}^{-2} \\
(48 \mathrm{~h})^{-1}\end{array}$ \\
\hline $\mathrm{PM}_{10}$ concentration & 1 & 3 & $1.746(0.797)$ & $1.013(0.639)$ & $0.847(0.241)$ & $0.786(0.399)$ & $0.948(0.449)$ \\
\hline$\left(\mathrm{mg} \mathrm{m}^{-3}\right)$ & 2 & 3 & $0.989(0.248)$ & $0.441(0.070)$ & $0.360(0.086)$ & $0.233(0.033)$ & $0.492(0.320)$ \\
\hline $\mathrm{PM}_{10}$ emission rate & 1 & 3 & $5.982(3.041)$ & $3.427(2.321)$ & $2.871(0.861)$ & $2.666(1.561)$ & $3.314(1.843)$ \\
\hline$\left(\mathrm{mg} \mathrm{h}^{-1} \operatorname{bird}^{-1}\right)$ & 2 & 3 & $2.753(0.737)$ & $1.285(0.317)$ & $1.072(0.495)$ & $0.591(0.121)$ & $1.197(0.349)$ \\
\hline $\mathrm{PM}_{2.5}$ concentration & 1 & 3 & $0.094(0.038)$ & $0.042(0.003)$ & $0.049(0.026)$ & $0.029(0.013)$ & $0.040(0.017)$ \\
\hline$\left(\mathrm{mg} \mathrm{m}^{-3}\right)$ & 2 & 3 & $0.058(0.010)$ & $0.019(0.010)$ & $0.017(0.009)$ & $0.019(0.007)$ & $0.028(0.012)$ \\
\hline $\mathrm{PM}_{2.5}$ emission rate & 1 & 3 & $0.248(0.154)$ & $0.070(0.014)$ & $0.082(0.075)$ & $0.033(0.029)$ & $0.066(0.059)$ \\
\hline$\left(\mathrm{mg} \mathrm{h}^{-1} \operatorname{bird}^{-1}\right)$ & 2 & 3 & $0.142(0.050)$ & $0.027(0.024)$ & $0.018(0.016)$ & $0.023(0.013)$ & $0.039(0.024)$ \\
\hline
\end{tabular}
emission rates in the two growth cycles for days on which oil spraying had already started (days 23, 30, and 33). 


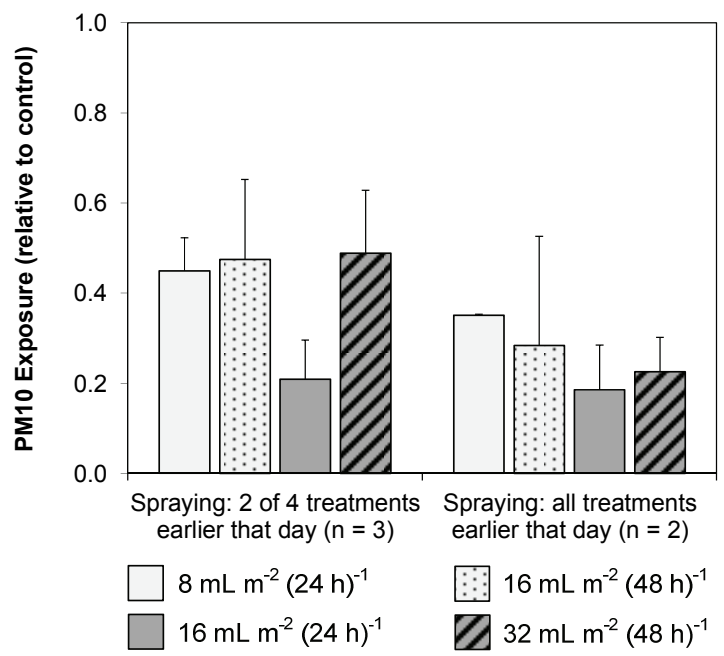

Figure 4. $\mathrm{PM}_{10}$ exposure (concentration at human breathing height) for the oil treatments, relative to the mean of control rooms. Error bars represent standard errors of the mean.

\section{Ammonia Emission}

Figure 5 shows the emission rate of ammonia throughout the first and second growth cycles. Emission patterns clearly differed between the two growth cycles but were similar between treatments, as seen by the treatment lines that mostly overlap each other. No significant differences were found in ammonia emissions between any of the treatments. The mean (SD between treatments) ammonia emission rate was $6.45(0.50) \mathrm{mg} \mathrm{h}^{-1}$ bird $^{-1}$ in the first growth cycle and $3.44(0.52) \mathrm{mg} \mathrm{h}^{-1}$ bird $^{-1}$ in the second growth cycle.

\section{ODOR EMISSION}

No significant differences were found in odor emission between any of the treatments. The mean (SD between treatments) odor emission rate was $0.78(0.18) \mathrm{OU}_{\mathrm{E}} \mathrm{s}^{-1}$ bird $^{-1}$ in the first growth cycle and $1.30(0.13) \mathrm{OU}_{\mathrm{E}} \mathrm{s}^{-1}$ bird $^{-1}$ in the second growth cycle.

\section{Animal Parameters}

Table 4 presents mean values of the birds' performance parameters. No significant differences were found in the performance parameters between any of the treatments, neither in the data for days 0 to 21 (before oil spraying had started) nor in the data for days 21 to 35 . We found no significant differences between treatments for foot-pad score, breast dirtiness, breast irritations, scabby hips (thigh scratches), and hock burns. The mean foot-pad score was
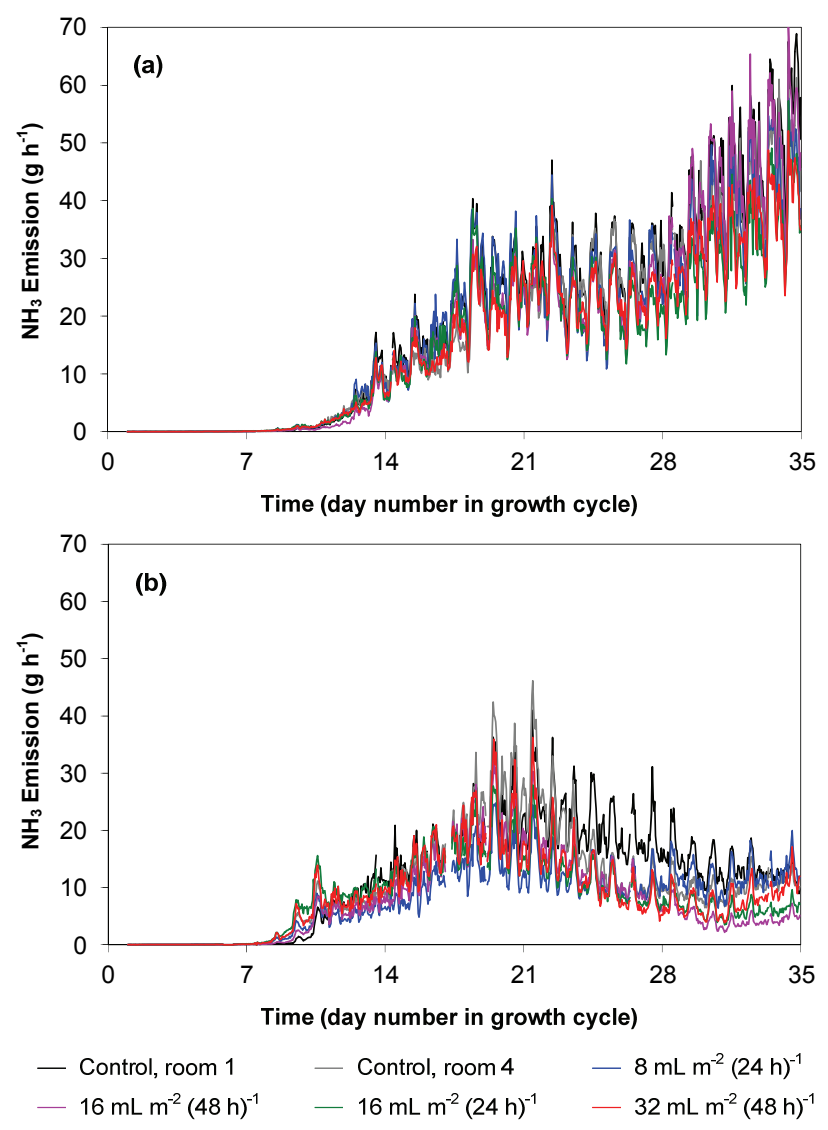

Figure 5. Ammonia $\left(\mathrm{NH}_{3}\right)$ emission rates during the (a) first and (b) second growth cycles. Note that the treatment lines mostly overlap.

88 for the control treatment, 82 for the $8 \mathrm{~mL} \mathrm{~m}^{-2}(24 \mathrm{~h})^{-1}$ treatment, 85 for the $16 \mathrm{~mL} \mathrm{~m}^{-2}\left(48 \mathrm{~h}^{-1}\right.$ treatment, 101 for the $16 \mathrm{~mL} \mathrm{~m}^{-2}(24 \mathrm{~h})^{-1}$ treatment, and 96 for the $32 \mathrm{~mL} \mathrm{~m}^{-2}$ $(48 \mathrm{~h})^{-1}$ treatment. The overall percentage of broilers falling in the "none" or "mild" classes was $60 \%$ for breast dirtiness, 96\% for breast irritations, 93\% for scabby hips, and $91 \%$ for hock burns.

\section{LitTER CHARACTERISTICS}

The dry matter content of the litter was similar between treatments. The mean (SEM) dry matter content of the litter was $62 \%(3 \%)$ for the control treatment, $66 \%$ (3\%) for the $8 \mathrm{~mL} \mathrm{~m}^{-2}(24 \mathrm{~h})^{-1}$ treatment, $63 \%(4 \%) 16 \mathrm{~mL} \mathrm{~m}^{-2}(48 \mathrm{~h})^{-1}$ treatment, $62 \%(3 \%)$ for the $16 \mathrm{~mL} \mathrm{~m}^{-2}(24 \mathrm{~h})^{-1}$ treatment, and $63 \%(3 \%)$ for the $32 \mathrm{~mL} \mathrm{~m}^{-2}(48 \mathrm{~h})^{-1}$ treatment. Between growth cycles, there were differences, with the litter being damper in the second growth cycle (range in room means: $64 \%$ to $69 \%$ ) than in the first (range in room means:

Table 4. Mean values of bird performance parameters over the two growth cycles (0 to 35 days). LSD: least significant difference.

\begin{tabular}{|c|c|c|c|c|c|c|}
\hline \multirow[b]{2}{*}{ Parameter } & \multirow{2}{*}{$\begin{array}{c}\text { Control } \\
\text { Rooms } \\
\left(0 \mathrm{~mL} \mathrm{~m}^{-2}\right)\end{array}$} & \multicolumn{2}{|c|}{$8 \mathrm{~mL} \mathrm{~m}^{-2} \mathrm{~d}^{-1}$} & \multicolumn{2}{|c|}{$16 \mathrm{~mL} \mathrm{~m}^{-2} \mathrm{~d}^{-1}$} & \multirow[b]{2}{*}{ LSD } \\
\hline & & $\begin{array}{c}8 \mathrm{~mL} \mathrm{~m}^{-2} \\
(24 \mathrm{~h})^{-1}\end{array}$ & $\begin{array}{c}16 \mathrm{~mL} \mathrm{~m}^{-2} \\
\left(48 \mathrm{~h}^{-1}\right.\end{array}$ & $\begin{array}{c}16 \mathrm{~mL} \mathrm{~m}^{-2} \\
(24 \mathrm{~h})^{-1}\end{array}$ & $\begin{array}{c}32 \mathrm{~mL} \mathrm{~m}^{-2} \\
\left(48 \mathrm{~h}^{-1}\right.\end{array}$ & \\
\hline Feed intake $\left(\mathrm{g} \mathrm{d}^{-1}\right.$ bird $\left.^{-1}\right)$ & 93.0 & 92.5 & 93.2 & 91.8 & 92.3 & 2.8 \\
\hline Feed conversion ( $\mathrm{g}$ feed $\mathrm{g}^{-1}$ growth) & 1.633 & 1.632 & 1.650 & 1.629 & 1.633 & 0.028 \\
\hline Water intake $\left(\mathrm{mL} \mathrm{d}^{-1}\right.$ bird $\left.^{-1}\right)$ & 161.4 & 160.3 & 161.7 & 159.9 & 161.6 & 5.3 \\
\hline Water/feed ratio (g water $\mathrm{g}^{-1}$ feed) & 1.74 & 1.74 & 1.74 & 1.74 & 1.75 & 0.04 \\
\hline Growth rate $\left(\mathrm{g} \mathrm{d}^{-1}\right.$ bird $\left.^{-1}\right)$ & 57.0 & 56.7 & 56.6 & 56.4 & 56.5 & 1.6 \\
\hline Weight at day $35(\mathrm{~g})$ & 2037 & 2026 & 2022 & 2016 & 2021 & 55 \\
\hline Mortality (\%) & 2.8 & 2.6 & 2.8 & 2.8 & 2.8 & 0.7 \\
\hline
\end{tabular}


$57 \%$ to $63 \%$ ). On day 14 of the second growth cycle, mean dry matter content of the litter inside the rooms was $70 \%$, which decreased in the second half of the cycle to mean levels of $52 \%$ on day 28 and $58 \%$ on day 35 . During the second half of the second growth cycle, approximately $20 \%$ of the litter area in the rooms was friable, but moist manure cake was present on $75 \%$ of the litter area. During the second half of the first growth cycle, manure cake was present on approximately $45 \%$ of the litter area in the rooms.

\section{CLEANING OF THE RoOMS}

After removal of the litter by a front loader, application of the soaking agent took approximately $9 \mathrm{~min}$, followed by 30 min of soaking time for all rooms. Pressure cleaning then took approximately $45 \mathrm{~min}$ for control rooms and $60 \mathrm{~min}$ for oil treatment rooms. The extra time for the oil treatment rooms was mainly needed for cleaning of the three ventilator shafts in each room.

\section{Discussion}

In the present study, we found a reduction in $\mathrm{PM}_{10}$ emission of $59 \%$ at an application rate of $8 \mathrm{~mL} \mathrm{~m}^{-2} \mathrm{~d}^{-1}$ and a reduction of $64 \%$ at an application rate of $16 \mathrm{~mL} \mathrm{~m}^{-2} \mathrm{~d}^{-1}$. Aarnink et al. (2011) found a relationship between these two parameters described by the equation $y=-0.021 x+$ $0.64\left(\mathrm{R}^{2}=0.69\right)$, where $y$ is the $\mathrm{PM}_{10}$ emission relative to the control treatment ( 0 to 1 ), and $x$ the oil application rate $\left(\mathrm{mL} \mathrm{m}^{-2} \mathrm{~d}^{-1}\right)$. The reductions found in the present study agree reasonably well with the values that can be calculated by fitting the oil application rates in the aforementioned equation, namely $53 \%$ for $8 \mathrm{~mL} \mathrm{~m}^{-2} \mathrm{~d}^{-1}$ and $70 \%$ for $16 \mathrm{~mL}$ $\mathrm{m}^{-2} \mathrm{~d}^{-1}$. Aarnink et al. (2011) found no relationship between oil application rate and $\mathrm{PM}_{2.5}$ reduction. At $6 \mathrm{~mL} \mathrm{~m}^{-2} \mathrm{~d}^{-1}$, $\mathrm{PM}_{2.5}$ emission was already reduced by $84 \%$, and this level did not increase further at higher application rates. In the present study, $\mathrm{PM}_{2.5}$ emission was reduced by $81 \%$ at $8 \mathrm{~mL}$ $\mathrm{m}^{-2} \mathrm{~d}^{-1}$ and by $74 \%$ at $16 \mathrm{~mL} \mathrm{~m}^{-2} \mathrm{~d}^{-1}$. The data from the present study confirm that, at the same oil application rate, $\mathrm{PM}_{2.5}$ emission is more reduced than $\mathrm{PM}_{10}$ emission, and increasing the application rate from 8 to $16 \mathrm{~mL} \mathrm{~m}^{-2} \mathrm{~d}^{-1}$ does not increase the $\mathrm{PM}_{2.5}$ reduction any further. Earlier, we hypothesized that some of the oil particles in the $\mathrm{PM}_{2.5}$ fraction might still be present in the air during PM sampling, cancelling out any extra $\mathrm{PM}_{2.5}$ reduction. This phenomenon could still play a role in the present study.

In the present study, emissions of $\mathrm{PM}_{10}$ or $\mathrm{PM}_{2.5}$ did not differ significantly between the two spraying frequencies (daily or every other day). However, on days after spraying, $\mathrm{PM}_{10}$ emission was $44 \%$ higher $(\mathrm{p}=0.05)$ than on spraying days. This suggests that the PM reduction is partially abolished on the second day after spraying. No significant difference was found for $\mathrm{PM}_{2.5}$ emission between spraying days and days after spraying. However, an actual increase in $\mathrm{PM}_{2.5}$ emission on the day after spraying might have been masked by elevated $\mathrm{PM}_{2.5}$ oil particle concentrations the day before.

Our findings on effects of oil spraying rate and spraying frequency can be compared with three available studies. In experimental pens housing broilers, Griffin and Vardaman (1970) applied 338 or $565 \mathrm{~mL}$ of cotton seed oil per $\mathrm{m}^{2}$ of litter floor area weekly (equivalent to 48 and $81 \mathrm{~mL} \mathrm{~m}^{-2} \mathrm{~d}^{-1}$, respectively) starting after the third week of the growth cycle. In that study, PM concentration within a 7-day spraying cycle increased with time after application, approximately doubling from day 1 to day 5 . In our previous study, we hypothesized that the oil forms a film on top of the litter floor that prevents particles in the litter from becoming airborne. If this truly is the main working principle, then agitation and mixing of the top layer of the litter by the broilers, and the ongoing deposition of fresh droppings on top of each oil film applied, may explain the diminishing PM reduction between oil applications. In a study by Drost et al. (1999) carried out in a broiler house, daily oil spraying using a fogging system that generated droplets with diameters smaller than $10 \mu \mathrm{m}$ reduced concentrations of respirable PM by only $12 \%$. The authors noted that the small droplets probably did not settle to the litter floor. These findings also point to a working principle based on an oil film on the litter floor rather than, for instance, a washout of particles from the air. In addition to the litter (i.e., manure and wood shavings), the feathers of the broilers contribute significantly to $\mathrm{PM}_{10}$ and $\mathrm{PM}_{2.5}$ mass concentrations in broiler houses (Cambra-López et al., 2011). Since the oil droplets from the oil spraying system settled to both the litter surface and the broilers, it is likely that the oil film acted as a binding agent on the aerosolization of feather particles as well. At the end of the growth cycle, the feathers of the broilers in the oil treatment rooms had a slight yellowish taint, whereas the feathers of the broilers in the control room were white. In a third study of broilers, McGovern et al. (1999) sprayed rapeseed oil onto the litter biweekly $\left(0.8 \mathrm{~L} \mathrm{~m}^{-2}\right.$ over a 42 -day growth cycle, equivalent to $\left.19 \mathrm{~mL} \mathrm{~m}^{-2} \mathrm{~d}^{-1}\right)$ and reported that the reduction in particle number concentration increased from no reduction in the first week, to $9 \%$ in the third week, $15 \%$ in the fourth week, and $40 \%$ in the fifth week. These results suggest that when large amounts of oil are sprayed at a time at low spraying frequencies, it may take considerable time for the oil to become fully effective. In the present study, we found no indications of a build-up of PM reduction over time during the second half of the growth cycle.

In the present study, PM concentrations in the control treatment ranged between 0.439 and $2.607 \mathrm{mg} \mathrm{m}^{-3}$ for $\mathrm{PM}_{10}$ and between 0.025 and $0.105 \mathrm{mg} \mathrm{m}^{-3}$ for $\mathrm{PM}_{2.5}$. It is clear that these levels are in excess of the exposure limits of $2.4 \mathrm{mg} \mathrm{m}^{-3}$ for inhalable PM $\left(\sim \mathrm{PM}_{100}\right)$ and $0.16 \mathrm{mg} \mathrm{m}^{-3}$ for respirable PM $\left(\sim \mathrm{PM}_{4}\right)$ recommended for pig and poultry workers (Donham and Cumro, 1999), even though the size fractions are not identical. Since the rooms were ventilated identically, the reported reductions in PM emission in this study are attributable to reductions in PM concentrations. It is noteworthy that similar or slightly higher reduction levels $(60 \%$ to $80 \%)$ were found by $\mathrm{PM}_{10}$ measurements at human breathing height during simulation of routine daily animal care activities, when broilers are stimulated to move and disperse particles into the air. These reductions are consistent with the levels found in our previous study (approx. $67 \%$ at $8 \mathrm{~mL} \mathrm{~m}^{-2} \mathrm{~d}^{-1}$ and $76 \%$ at $16 \mathrm{~mL} \mathrm{~m}^{-2} \mathrm{~d}^{-1}$ ). This aspect 
can be regarded as an important advantage of oil spraying in comparison to "end of pipe" abatement systems.

In line with Aarnink et al. (2011), we found no effect of oil spraying on the emission rate of ammonia. Patterns in ammonia emission rate were similar between treatments, but clear differences were present between the two growth cycles. In the first growth cycle, the ammonia emission rate increased during the first three weeks, stabilized at a high level in the fourth week, and finally increased again in the last week. In the second growth cycle, an increase during the first three weeks was followed by a decline in emission rate. The higher water content of the litter and the formation of solid manure cake during the second half of the second growth cycle were probably unfavorable conditions for ammonia production and volatilization (Chepete et al., 2012; Liu et al., 2007). Oil spraying had no effect on the dry matter content of the litter, which agrees with the findings of Griffin and Vardaman (1970). In the present study, we investigated for the first time the effects of oil spraying on odor emission and found that odor emission rate did not differ significantly between treatments. Apparently, the oil film is effective in aggregating particles in the litter for a certain amount of time, but the production and release of gaseous ammonia and odorous compounds from the litter remain unaffected. However, it must be noted that the air samples for odor analysis were filtered during sampling. Therefore, any reduction of odorous compounds by adsorption to particles may have been missed.

An important side-effect noted by Aarnink et al. (2011) was a significantly higher mean foot-pad score of the broilers in the $24 \mathrm{~mL} \mathrm{~m}^{-2} \mathrm{~d}^{-1}$ treatment in comparison to the control treatment. In the present study, we tried to prevent this by starting with oil spraying only from day 21 of the growth cycle, by limiting the oil application rate to $16 \mathrm{~mL}$ $\mathrm{m}^{-2} \mathrm{~d}^{-1}$, and by spraying the oil more uniformly over the litter area in the second growth cycle. Using this approach, we did not find an effect of oil spraying on the foot-pad score of the broilers. In the present study as well as in the previous study, we found no effect of oil spraying on bird performance parameters (feed intake, feed conversion, water intake, water/feed ratio, growth rate, end weight, and mortality). Earlier, McGovern et al. (2000) reported a significantly lower end weight of broilers housed on straw that was treated biweekly with rapeseed oil $\left(1.1 \mathrm{~L} \mathrm{~m}^{-2}\right.$ over six weeks, equivalent to $26 \mathrm{~mL} \mathrm{~m}^{-2} \mathrm{~d}^{-1}$ ), which the authors explained by a higher body heat loss caused by oil contamination of the feathers or due to consumption of oiled straw. In agreement with these possible explanations, Griffin and Vardaman (1970) observed that broilers scratched more in litter that had just been sprayed and that their feathers became oily from contact with the litter. In contrast to McGovern et al. (2000), we used a lower oil application rate, and no oil was sprayed during the first three weeks of the growth cycle. Furthermore, neither negative nor positive effects on broiler performance were found by Griffin and Vardaman (1970) at 338 or $565 \mathrm{~mL} \mathrm{~m}^{-2}$ week $^{-1}$, starting at three weeks of age, and by McGovern et al. (1999) at $800 \mathrm{~mL} \mathrm{~m}^{-2}$ over six weeks.

In the present study, we experienced oil leakage from the nozzles of the oil spraying system, which was previous- ly identified as well (Aarnink et al., 2011). A possible cause for this could be that the timer-controlled valves did not shut immediately and completely after spraying due to pollution. To rule this out, we disassembled and cleaned the valves prior to both growth cycles, and we filtered the rapeseed oil during each filling of the oil tank. However, this did not solve the oil leakage. The following options could solve this problem and improve the system in general:

- The oil tank, main oil tube, and branched oil tubes could be placed below the level of the nozzles in the room to eliminate the oil pressure resulting from gravity. The oil tank in this study was positioned in the attic of the building, higher than the nozzles.

- The oil and air pressure could be shut off completely between spraying moments. In the current system, oil and air pressure were maintained on the main tubes (up to the timer-controlled valves) between spraying moments.

- A timer-controlled valve could be used directly upstream of each nozzle, so that very little oil would remain available for leakage in the length of tube between the valve and the nozzle.

- The air pressure could be applied shortly before opening the oil valves up to some time after shutting of the oil valves, to fog any leaking drops or trickles into the air, and to clean the nozzles after each spraying moment.

To reduce the generation of small oil particles, we brought the oil and air pressure down in the second growth cycle from 3.5 to 3.0 bar, which reduced the spray velocity from 8.4 to $7.2 \mathrm{~m} \mathrm{~s}^{-1}$ and increased the volume median diameter $\left(D_{V 0.5}\right)$ of the oil droplets from 44 to $49 \mu \mathrm{m}$ (Aarnink and Van Hattum, 2009). To compensate for the smaller litter area sprayed per nozzle at these lower pressure settings, and to improve the distribution of oil over the litter floor, we doubled the number of nozzles per room (fig. 1). Using equation 2, we estimated the mean (SEM) percentage of the total volume of oil applied sampled as airborne oil particles to be $1.84 \%(0.26 \%)$ in the $\mathrm{PM}_{10}$ fraction and $0.34 \%(0.02 \%)$ in the $\mathrm{PM}_{2.5}$ fraction. When applying this equation to the dataset of Aarnink et al. (2011), where the oil and air pressure was 3.5 bar, these values were $1.87 \%(0.22 \%)$ for $\mathrm{PM}_{10}$ and $0.39 \%(0.03 \%)$ for $\mathrm{PM}_{2.5}$. Thus, the reduction of oil and air pressure in the second growth cycle of the present study did not result in a substantial shift toward larger oil droplets.

\section{Conclusions}

In this follow-up study, we further investigated the effects of oil spraying rate and spraying frequency inside an experimental broiler house in four oil treatment $\left(8 \mathrm{~mL} \mathrm{~m}^{-2}\right.$ $\left(24 \mathrm{~h}^{-1}, 16 \mathrm{~mL} \mathrm{~m}^{-2}(48 \mathrm{~h})^{-1}, 16 \mathrm{~mL} \mathrm{~m}^{-2}(24 \mathrm{~h})^{-1}\right.$, and $32 \mathrm{~mL}$ $\left.\mathrm{m}^{-2}(48 \mathrm{~h})^{-1}\right)$, relative to a control treatment $\left(0 \mathrm{~mL} \mathrm{~m}^{-2}\right)$. The oil treatments were randomly assigned to four rooms, and two rooms served as control. The experiment lasted for two consecutive growth cycles. In both growth cycles, oil spraying started on day 21 . Our main results and conclusions are: 
- The oil spraying system effectively reduced concentrations and emissions of $\mathrm{PM}_{10}$ and $\mathrm{PM}_{2.5}$. The reduction in $\mathrm{PM}_{10}$ emission was $59 \%$ for $8 \mathrm{~mL} \mathrm{~m}^{-2} \mathrm{~d}^{-1}$ and $64 \%$ for $16 \mathrm{~mL} \mathrm{~m}^{-2} \mathrm{~d}^{-1}$. The reduction in $\mathrm{PM}_{2.5}$ emission was $81 \%$ for $8 \mathrm{~mL} \mathrm{~m}^{-2} \mathrm{~d}^{-1}$ and $74 \%$ for $16 \mathrm{~mL} \mathrm{~m}^{-2} \mathrm{~d}^{-1}$. No significant difference in particulate matter (PM) emission was found between the 8 and $16 \mathrm{~mL} \mathrm{~m}^{-2} \mathrm{~d}^{-1}$ applications.

- Emissions of $\mathrm{PM}_{10}$ and $\mathrm{PM}_{2.5}$ were not significantly different between oil spraying frequencies (daily or every other day). However, $\mathrm{PM}_{10}$ emission on days after spraying was $44 \%$ higher than on days of spraying. This suggests that PM reduction is partially abolished on the second day after spraying.

- The extension of the system from 8 to 16 oil spraying nozzles per room, implemented prior to the second growth cycle, improved the equal distribution of oil over the litter floor. A reduction of the oil and air pressure from 3.5 to 3.0 bar resulted in a substantial shift toward larger oil droplets.

- The reduction in stock handlers' exposure to $\mathrm{PM}_{10}$ during daily routine activities ranged between $60 \%$ and $80 \%$, even though the birds were stimulated to move and disperse particles into the air. Thus, oil spraying can contribute to the protection of workers inside broiler houses against hazardous PM levels.

- Our results show that the oil treatments tested did not affect ammonia emission, odor emission, bird performance, birds' exterior quality, and litter dry matter content.

- This study confirms that incidence of foot-pad lesions is not significantly increased with a maximum oil application rate of $16 \mathrm{~mL} \mathrm{~m}^{-2} \mathrm{~d}^{-1}$, starting from day 21 of the growth cycle.

- It is recommended to validate the effect of oil spraying in full-scale commercial broiler houses at a daily application of $16 \mathrm{~mL} \mathrm{~m}^{-2}$ or less starting from day 21 of the growth cycle.

\section{ACKNOWLEDGEMENTS}

This study was financed by the Dutch Ministry of Economic Affairs and the Dutch Ministry of Infrastructure and the Environment. We thank the staff of the Spelderholt experimental station for taking care of the animals, Mr. Theo van Hattum for maintenance of the oil spraying system, Mr. Eef Lovink for maintenance and calibration of measuring equipment, Mr. Jean Slangen for carrying out the laboratory analyses, and Mr. Johan van Riel for advice on the statistical analysis.

\section{REFERENCES}

Aarnink, A. J. A., \& Van Hattum, T. G. (2009). Measures to reduce fine dust emission from poultry houses: Laboratory study characterizing oil spraying nozzles (droplet size and velocity) [in Dutch with English summary]. Report 229. Lelystad, The Netherlands: Wageningen University and Research Centre, Animal Sciences Group.

Aarnink, A. J. A., Van Harn, J., Van Hattum, T. G., Zhao, Y., \& Ogink, N. W. M. (2011). Dust reduction in broiler houses by spraying rapeseed oil. Trans. ASABE, 54(4), 1479-1489. http://dx.doi.org/10.13031/2013.39028.

Al Homidan, A., Robertson, J. F., \& Petchey, A. M. (2003). Review of the effect of ammonia and dust concentrations on broiler performance. World's Poultry Sc. J., 59(3), 340-349. http://dx.doi.org/10.1079/WPS20030021.

Berg, C. (1998). Footpad dermatitis in broilers and turkeys: Prevalence, risk factors, and prevention. $\mathrm{PhD}$ diss. Uppsala, Sweden: Swedish University of Agricultural Science.

Brunekreef, B., \& Holgate, S. T. (2002). Air pollution and health. Lancet, 360(9341), 1233-1242. http://dx.doi.org/10.1016/S01406736(02)11274-8.

Cambra-López, M., Hermosilla, T., Lai, H. T. L., Aarnink, A. J. A., \& Ogink, N. W. M. (2011). Particulate matter emitted from poultry and pig houses: Source identification and quantification. Trans. ASABE, 54(2), 629-642. http://dx.doi.org/10.13031/2013.36466.

CEN. (1998). EN 12341: Air quality - Determination of the $\mathrm{PM}_{10}$ fraction of suspended particulate matter - Reference method and field test procedure to demonstrate reference equivalence of measurement methods. Brussels, Belgium: European Committee for Standardization.

CEN. (2003). EN 13725: Air quality-Determination of odour concentration by dynamic olfactometry. Brussels, Belgium: European Committee for Standardization.

CEN. (2005). EN 14907: Ambient air quality—Standard gravimetric measurement method for the determination of the $\mathrm{PM}_{2.5}$ mass fraction of suspended particulate matter. Brussels, Belgium: European Committee for Standardization.

Chepete, H. J., Xin, H., \& Li, H. (2012). Effect of partially covering the turkey litter surface on ammonia emission. J. Appl. Poultry Res., 21(3), 513-521. http://dx.doi.org/10.3382/japr.2011-00419.

Donham, K., \& Cumro, D. (1999). Setting maximum dust exposure levels for people and animals in livestock facilities. In Proc. Intl. Symp. Dust Control in Animal Production Facilities (pp. 93110). Aarhus, Denmark: Danish Institute of Agricultural Sciences.

Drost, H., Beens, N., Dolehghs, B., Ellen, H., \& Oude Vrielink, H. H. E. (1999). Is fogging water or oil effective in reducing dust concentrations in poultry houses? In Proc. Intl. Symp. Dust Control in Animal Production Facilities (pp. 231-236). Aarhus, Denmark: Danish Institute of Agricultural Sciences.

EU. (2008). Directive 2008/50/EC of the European Parliament and of the Council of 21 May 2008 on ambient air quality and cleaner air for Europe. Off. J. European Union, L152, 1-44.

Griffin, J. G., \& Vardaman, T. H. (1970). Cottonseed oil spray for broiler houses: Effects on dust control, Mycoplasma gallisepticum spread, and broiler performances. Poultry Sci., 49(6), 1664-1668. http://dx.doi.org/10.3382/ps.0491664.

Liu, Z., Wang, L., Beasley, D., \& Oviedo, E. (2007). Effect of moisture content on ammonia emissions from broiler litter: A laboratory study. J. Atmos. Chem., 58(1), 41-53. http://dx.doi.org/10.1007/s10874-007-9076-8.

Madelin, T. M., \& Wathes, C. M. (1989). Air hygiene in a broiler house: Comparison of deep litter with raised netting floors. British Poultry Sci., 30(1), 23-37. http://dx.doi.org/10.1080/00071668908417122.

McGovern, R. H., Feddes, J. J. R., Robinson, F. E., \& Hanson, J. A. (1999). Growth performance, carcass characteristics, and the incidence of ascites in broilers in response to feed restriction and litter oiling. Poultry Sci., 78(4), 522-528. http://dx.doi.org/10.1093/ps/78.4.522.

McGovern, R. H., Feddes, J. J. R., Robinson, F. E., \& Hanson, J. A. (2000). Growth, carcass characteristics, and incidence of ascites in broilers exposed to environmental fluctuations and oiled litter. Poultry Sci., 79(3), 324-330. 
http://dx.doi.org/10.1093/ps/79.3.324.

Ogink, N. W. M., \& Aarnink, A. J. A. (2011). Plan van aanpak bedrijfsoplossingen voor fijnstofreductie in de pluimveehouderij [Plan of action for particulate matter mitigation solutions in poultry; in Dutch with English summary]. Report 113. Lelystad, The Netherlands: Wageningen University and Research Centre, Animal Sciences Group.

Omland, Ø. (2002). Exposure and respiratory health in farming in temperate zones: A review of the literature. Ann. Agric. Environ. Med., 9(2), 119-136.

Radon, K., Danuser, B., Iversen, M., Jörres, R., Monso, E., Opravil, U., Weber, C., Donham, K. J., \& Nowak, D. (2001). Respiratory symptoms in European animal farmers. European Resp. J., 17(4), 747-754.

http://dx.doi.org/10.1183/09031936.01.17407470.

RIVM. (2014). Annual national emissions of $\mathrm{PM}_{10}$; in total and per sector/source, for 2012. Bilthoven, The Netherlands: National Institute for Public Health and the Environment (RIVM). Retrieved from http://www.emissieregistratie.nl/erpubliek/ erpub/selectie/criteria.aspx.
Takai, H. (2007). Factors influencing dust reduction efficiency of spraying of oilwater mixtures in pig buildings. In Proc.

DustConf 2007: How to Improve Air Quality. Maastricht, The Netherlands. Retrieved from

www.dustconf.org/client/dustconf/upload/S6/takai_dk.pdf.

Van Harn, J. (2009). Comparison of four light schedules according to EU Directive 2007/43 for broilers [in Dutch with English summary]. Report 172. Lelystad, The Netherlands: Wageningen University and Research Centre, Animal Sciences Group.

VSN. (2012). GenStat reference manual (release 15). Ver. 15.2.0.8821. Hemel Hempstead, U.K.: VSN International, Ltd.

Winkel, A., Mosquera, J., Groot Koerkamp, P. W. G., Ogink, N. W. M., \& Aarnink, A. J. A. (2014). Emissions of particulate matter from animal houses in the Netherlands. (submitted for publication).

Zhao, Y., Aarnink, A. J. A., Hofschreuder, P., \& Groot Koerkamp, P. W. G. (2009). Evaluation of an impaction and a cyclone preseparator for sampling high $\mathrm{PM}_{10}$ and $\mathrm{PM}_{2.5}$ concentrations in livestock houses. J. Aerosol Sci., 40(10), 868-878. http://dx.doi.org/10.1016/j.jaerosci.2009.06.001. 